\title{
MELIMEX, an experimental heavy metal pollution study: Regulation of trace metal concentrations in limno-corrals
}

\author{
By P. Baccini, J. Ruchti, O. Wanner and E. Grieder \\ Swiss Federal Institute for Water Resources and Water Pollution Control (EAWAG) at Swiss Federal
} Institutes of Technology (ETH)

Manuscript received on 28 June 1979

\section{ABSTRACT}

In three limno-corrals of the MELIMEX project the transport paths of the trace metals $\mathrm{Cu}, \mathrm{Zn}$, $\mathrm{Cd}, \mathrm{Hg}$ and $\mathrm{Pb}$ and the reaction of the systems on increased metal loads were investigated. The metal balances lead to the conclusion that the biomass is the main factor responsible for the regulation of trace metal concentration. The observed sequence of relative residence times of the trace metals can be described with a steady-state model. Additional metal load decreases the ability of the limnic system to lower the metal concentration. The production of phytoplankton and its assimilation capacity for metals are reduced leading to relatively higher metal concentrations in the lake.

\section{List of symbols}

[BM] Concentration of metal in biomass [mole $/ \mathrm{kg}$ dry matter]

C Control corral

c Quantity of metal in the corral [mole]

Ac Quantity of metal taken up or released by the corral [mole]

$D_{M} \quad$ Distribution coefficient $\left[\mathrm{m}^{3} \mathrm{~kg}^{-1}\right]$

[DM] Concentration of dissolved metal in the corral [M]

$\mathrm{e}_{\mathrm{r}} \quad$ Random error of the metal balance [mole]

$e_{s} \quad$ Systematic error of the metal balance [mole]

F Area of the corral bottom $\left[\mathrm{m}^{2}\right]$

$\left[\mathrm{FH}_{\mathrm{g}}\right]$ Concentration of filterable $\mathrm{Hg}$ fraction [M]

$\mathrm{HZ}$ Hydrozincite

i Quantity of metal in the inflow [mole]

$j \quad$ Index of sampling interval

$\mathrm{K}_{\text {so }} \quad$ Solubility product

L1, L2 Loaded corrals

M Index for metal

MC Metal carbonate

o Quantity of metal in the outflow [mole]

[P] Concentration of biomass [ $\mathrm{kg}$ dry matter $\left.\mathrm{m}^{-3}\right]$

[PM] Concentration of particulate metal [mole $\mathrm{m}^{-3}$ ]

[PN] Concentration of particulate Kjeldahl nitrogen [ $\mathrm{mg} \mathrm{m}^{-3}$ ]

pP Negative logarithm of the calculated solubility products

pO Negative logarithm of the observed solubility products 
Q Water flux to and from limno-corrals $\left[\mathrm{m}^{3} \mathrm{~d}^{-1}\right]$

Qs Sedimentation flux $\left[\mathrm{m}^{3} \mathrm{~d}^{-1}\right]$

$s$ Quantity of metal sedimented in the corral [mole]

[SN] Sedimentation of Kjeldahl nitrogen $\left[\mathrm{mg} \mathrm{m}^{-2} \mathrm{~d}^{-1}\right]$

$\sigma \quad$ Sedimentation rate $\left[\mathrm{m} \mathrm{d}^{-1}\right]$

[TM] Concentration of total metal in the corral [M]

$\left[\mathrm{TM}_{\mathrm{i}}\right]$ Concentration of total metal in the inflow [M]

$\Delta \mathrm{t}$ Observation period [d]

$[\mathrm{VHg}]$ Concentration of volatile mercury fraction $[\mathrm{M}]$

$\mathrm{W}_{\mathrm{M}}$ Rate of adsoprtion of metal $\mathrm{M}$ at the corral wall [mole $\mathrm{d}^{-1}$ ]

\section{Introduction}

In order to elucidate a lake's role in the cycle of heavy metals one has to know its capacity to influence the transport paths of these elements. Previous investigations of natural lakes $[1,2]$ lead to the conclusion that heavy metals $(\mathrm{Fe}, \mathrm{Cu}$, $\mathrm{Zn}, \mathrm{Cd}, \mathrm{Pb}$ ) on allochthonous particles are sedimented almost quantitatively. The incoming dissolved forms are partially retained by the assimilation processes of the lake's biomass. Estimations of the anthropogenic portions of the heavy metal loading of lakes [3] show that the input of these elements is significantly increased by man's activities in the catchment area. Furthermore this additional loading is overlapped by discharges of phosphorous leading to eutrophication. Therefore a lake's response to increased heavy metal input cannot be evaluated properly under natural conditions.

The MELIMEX model lakes [4] permit comparison of the effects of an increased metal load in systems which are hardly influenced by allochthonous particles, except by the direct input of atmospheric fallout. Therefore the retention ability of the model lakes should be due primarily to the biomass activity within the system. A disadvantage of the limno-corrals arises from two facts, namely

a) the ratio of sediment surface to water volume is similar to the one of a shallow lake. Examples of natural systems with known metal fluxes are mostly of greater depth;

b) the artificial cylindrical wall with a surface almost four times as large as the sediment bottom represents an unusual limnic interphase whose role could not be forseen at the beginning of the experiment.

The present work intends to focus on the main factors which are responsible for the regulation of the concentrations of the trace metals copper, zinc, cadmium, mercury and lead. The distinction between physical, chemical and biological phenomena of the metal distribution is considered to be one necessary element for the development of a dynamic limnological metal model.

\section{Methods}

Three limno-corrals of $12 \mathrm{~m}$ in diameter and of a mean depth of $10 \mathrm{~m}$ were installed at the northern end of Lake Baldegg. A system of pumps was used to pump water into and out of the limno-corrals. One corral served as control (C). Its metal concentrations were identical to ambient concentrations of the lake. Two 
corrals $(\mathrm{L} 1, \mathrm{~L} 2)$ had the following average inflow-concentrations of metals $\left(10^{-8} \mathrm{M}\right)$ :

- Copper: 18,

- zinc: 320 ,

- cadmium: 4.5 ,

- mercury: 0.5 ,

- lead: 24 .

These values correspond to the maximum concentrations tolerated legally in Swiss running waters.

Detailed informations about the experimental design of the MELIMEX project are given by Gächter [4].

\subsection{Sample collection}

\subsection{Lake water}

Samples for the concentration profile of metals and complementary parameters were drawn every 2 weeks or monthly from depths of $0,2.5,5,7.5 \mathrm{~m}$ and above bottom $(9.5-10 \mathrm{~m})$ in Niskin bottles. The natural metal concentration of the incoming water was determined from the concentration of surface waters of the middle of Lake Baldegg for the year 1977. For the rest of the experimental run in 1978 the natural concentration was determined from samples taken directly from the inflow of control corral C.

\subsection{Sediments}

\subsection{Sedimentation samples}

Each container was equipped with four sediment traps, two at a depth of $5 \mathrm{~m}$ and two above ground $(9.5-10 \mathrm{~m})$, each at a distance of 3-4 $\mathrm{m}$ from the walls. The sediment traps were made of acrylresin cylinders with a diameter of $14 \mathrm{~cm}(29 \mathrm{~cm})$ and a height of $50 \mathrm{~cm}$ for the period from 21.3 .77 to $8.12 .77(8.12 .77-26.6 .78)$. The sediment samples were collected monthly.

\subsection{Sediment cores}

Sediment cores were taken in January 1978 (by a diver) in acrylresin tubes with a diameter of $31 \mathrm{~mm}$ and a height of $30 \mathrm{~cm}$. The cores ranged from 15 to $20 \mathrm{~cm}$.

\subsection{Periphyton}

During the experiment it was observed that a substantial layer of biomass developed on the inner surface of the corral walls. For the determination of the metal content of this periphyton, wall areas of $0.1-0.5 \mathrm{~m}^{2}$ were scratched off at a depth of $0.5-1.0 \mathrm{~m}$. 


\subsection{Chemical analysis}

\subsection{Metals in lake water}

\subsection{Fractioning}

For the metals $\mathrm{M}=\mathrm{Cu}, \mathrm{Zn}, \mathrm{Cd}$ and $\mathrm{Pb}$ the total concentration $\mathrm{TM}$ and the dissolved fraction DM after filtration through a $0.45 \mu \mathrm{m}$ filter (Millipore) were determined. The filter was washed with distilled water and $500 \mathrm{ml}$ of the sample in order to avoid adsorption losses. The particulate fraction PM was calculated from the difference of TM and DM.

The total mercury was divided as follows: 11 of the sample was aerated for 24 hours to remove the volatile fraction $(\mathrm{VHg})$ into $100 \mathrm{ml}$ of an acid $\mathrm{KMnO}_{4}$ solution. By this method elementary $\mathrm{Hg}$ dissolved in water can be removed. Dimethylmercury is not removed in this step. The aerated sample was filtered $(\mathrm{FHg})$ through a glassfiber filter (GF/C Whatman) coated with magnesium hydroxide carbonate. The retained fraction contains the particulate fraction $(\mathrm{PHg})$. The total mercury $(\mathrm{THg})$ is the sum of the three fractions. The dissolved fraction $\mathrm{DHg}$ consists of $\mathrm{VHg}$ and $\mathrm{FHg}$.

\subsection{Concentration step}

For the analysis of $\mathrm{Cu}, \mathrm{Cd}$ and $\mathrm{Pb} 500 \mathrm{ml}$ of the samples were spiked with $200 \mu \mathrm{l}$ concentrated $\mathrm{HCl}$ and $100 \mu \mathrm{H}_{2} \mathrm{O}_{2}$ and concentrated by evaporation to a volume of $25 \mathrm{ml}$.

\subsection{Measurement by atomic absorption spectroscopy}

A Perkin-Elmer AAS 400 with a graphite furnace HGA 74 was used. The conditions are summarized in table 1 . For mercury the method described by Hatch and Ott [23] ('cold procedure') was applied. In a preliminary step the $\mathrm{PHg}$ fraction on the filter was heated in a $250 \mathrm{ml}$ glass bottle with $10 \mathrm{ml}$ conc. $\mathrm{H}_{2} \mathrm{SO}_{4}$ and $100 \mu \mathrm{H} \mathrm{H}_{2} \mathrm{O}_{2}$ at $60^{\circ} \mathrm{C}$ during 12 hours. It was diluted with distilled water to $100 \mathrm{ml} .100 \mathrm{ml}$ of the

Table 1. Analysis of metals in lake water samples by AAS.

Tabelle 1. Metallanalytik von Seewasserproben mit AAS.

\begin{tabular}{|c|c|c|c|c|c|}
\hline & $\mathrm{Cu}$ & $\mathrm{Zn}$ & $\mathrm{Cd}$ & $\mathrm{Hg}$ & $\mathrm{Pb}$ \\
\hline Wavelength (nm) & 324.7 & 213.8 & 228.8 & 253.6 & 283.3 \\
\hline $\begin{array}{l}\text { Detection limit relative to lake water } \\
\left(10^{-9} \mathrm{M}\right)\end{array}$ & 2 & 10 & 0.1 & $\begin{array}{l}0.1(\mathrm{~V}, \mathrm{P}) \\
0.5(\mathrm{~F})\end{array}$ & 1 \\
\hline $\begin{array}{l}\left.\text { Analytical error }{ }^{1}\right)(\%) \\
\text { for concentration ranges of }\end{array}$ & & & & & \\
\hline - loaded corrals & 4 & 6 & 4 & $\begin{array}{l}12(\mathrm{P}) \\
\left.25(\mathrm{~F}, \mathrm{~V})^{2}\right)\end{array}$ & 5 \\
\hline - control & 7 & 13 & 18 & - & 20 \\
\hline
\end{tabular}

1) Defined as standard deviation of 10 samples of the same sampling position.

2) The mercury concentration in the control container is not detectable, $\mathrm{V}=$ volatile, $\mathrm{P}=$ particulate, $\mathrm{F}=$ filterable. 
FHg fraction and $100 \mathrm{ml}$ of the collected $\mathrm{VHg}$ fraction were measured according to the above mentioned method. Dissolved dimethylmercury is not detectable by this method (digestion step is not sufficient).

\subsection{Metals in sediments}

\section{Digestion step}

For the elements $\mathrm{Cu}, \mathrm{Zn}, \mathrm{Cd}$ and $\mathrm{Pb} 50 \mathrm{mg}$ of dried sediment were heated in $1 \mathrm{ml}$ pure $\mathrm{H}_{2} \mathrm{SO}_{4}$ and $4 \mathrm{ml} \mathrm{H}_{2} \mathrm{O}_{2}$ during 30 minutes at $260{ }^{\circ} \mathrm{C}$. The sample was then diluted with distilled water to $50 \mathrm{ml}$.

For $\mathrm{Hg} 50 \mathrm{mg}$ of dried sediment were heated in $10 \mathrm{ml}$ pure $\mathrm{H}_{2} \mathrm{SO}_{4}$ and $1.5 \mathrm{ml} \mathrm{H}_{2} \mathrm{O}_{2}$ during 12 hours at $60^{\circ} \mathrm{C}$. It was then diluted with distilled water to $100 \mathrm{ml}$.

\section{Measurement of metals by $A A S$}

The elements $\mathrm{Cu}, \mathrm{Cd}$ and $\mathrm{Pb}$ were measured by the flameless method (see 2.213). Zinc was measured in the flame according to the standard method described by Perkin-Elmer. Mercury was determined by the method mentioned in 2.213. The limits of the analytical procedure are presented in table 2 .

Table 2. Analysis of metals in dry matter by AAS.

Tabelle 2. Metallanalyse von Trockensubstanz mit AAS.

\begin{tabular}{lccccc}
\hline & $\left.\mathrm{Cu}^{2}\right)$ & $\left.\mathrm{Zn}^{3}\right)$ & $\left.\mathrm{Cd}^{2}\right)$ & $\left.\mathrm{Hg}^{2}\right)$ & $\left.\mathrm{Pb}^{2}\right)$ \\
\hline $\begin{array}{l}\text { Detection limit } \\
\left(10^{-8} \text { mole/g dry matter) }\right.\end{array}$ & 5 & 100 & $\mathrm{I}$ & 0.1 & 5 \\
Analytical error $\left.{ }^{1}\right)(\%)$ & & & & & \\
- loaded corrals & 9 & 6 & 6 & 9 & 9 \\
- control & 18 & 18 & 10 & 23 & 19 \\
\hline
\end{tabular}

1) Standard deviation of 10 samples of left and right sediment traps at the same height in the same period.

2) Flameless method.

3) Measured in the flame.

\subsection{Complementary parameters}

The dry matter and the organic fraction (loss on ignition) of sediments were determined with methods described in [5]. In the acid soluble fraction of the dried sediment calcium was determined by a complexometric method [6]. Particulate organic nitrogen in lake water and organic nitrogen in sediments were determined according to Stadelmann [7].

\subsection{Metal balance}

\subsection{Evaluation of analytical data}

The experimental period is divided into 20 intervals. At the begin of the experiment and at the end of each interval $j$ the metal concentrations were measured. 
For each interval boundary the mean quantity of a metal in the corral, c, was calculated from the concentrations TM measured at the depths of $0 \mathrm{~m}, 2.5 \mathrm{~m}, 5 \mathrm{~m}$, $7.5 \mathrm{~m}$ and at the bottom:

$$
\mathrm{c}=\frac{\mathrm{V}}{4}\left(\frac{1}{2} \mathrm{TM}_{0 \mathrm{~m}}+\mathrm{TM}_{2.5 \mathrm{~m}}+\mathrm{TM}_{5.0 \mathrm{~m}}+\mathrm{TM}_{7.5 \mathrm{~m}}+\frac{1}{2} \mathrm{TM}_{\text {bottom }}\right)
$$

where $\mathrm{V}$ is the total volume of the corral.

Furthermore the following quantities were defined for each interval:

Input, $\mathrm{i}_{\mathrm{j}}$ : The quantity of metal in the inflow calculated from the running time of the water and dosage pumps and the known concentrations of the reservoirs (metal solutions and Lake Baldegg).

Output, $o_{j}$ : The quantity of metal in the outlet calculated from the running time of the water pump and the concentration of the metal at begin and end of the jth interval, at $1.25 \mathrm{~m} \mathrm{TM}_{\mathrm{j}, 1.25 \mathrm{~m}}=\left(\mathrm{TM}_{\mathrm{j}, 0 \mathrm{~m}}+\mathrm{TM}_{\mathrm{j}, 2.5 \mathrm{~m}}\right) / 2$.

Corral, $\Delta c_{j}$ : The quantity of metal, which is taken up or released by the aequeous phase of the corral during an interval $\mathrm{j}$ is calculated as

$$
\Delta \mathrm{c}_{\mathrm{j}}=\mathrm{c}_{\mathrm{j}}-\mathrm{c}_{\mathrm{j}-1} .
$$

$\Delta \mathrm{c}_{\mathrm{j}}$ can be positive or negative.

Sediment, $s_{j}$ : The quantity of metal deposited in the sediment traps during the $j$ th interval, extrapolated to the overall bottom area of the corral.

\subsection{Balance equation}

With the elements defined above the following metal balance was calculated:

$$
\mathrm{i}-\mathrm{o}-\Delta \mathrm{c}-\mathrm{s}+\mathrm{e}=0
$$

where $i, o, s$ are the sums of $i_{j}, o_{j}, s_{j}$ for $j=1 \cdots 20$ and the change of metal in the aqueous phase is

$$
\triangle \mathrm{c}=\mathrm{c}_{20}-\mathrm{c}_{0} .
$$

The error e of the balance will be discussed in section 4.11 .

Programs evaluating the above balance euqation and for statistical analysis were written in PASCAL and run on the CDC-6000 system at the computing center at the Swiss Federal Institute of Technology in Zürich.

\section{Results}

\subsection{The dynamics of metal concentration in the limno-corrals}

The isopleths presented in figures 1 and 2 for total concentrations of copper and zinc exemplify the following main characteristics: 

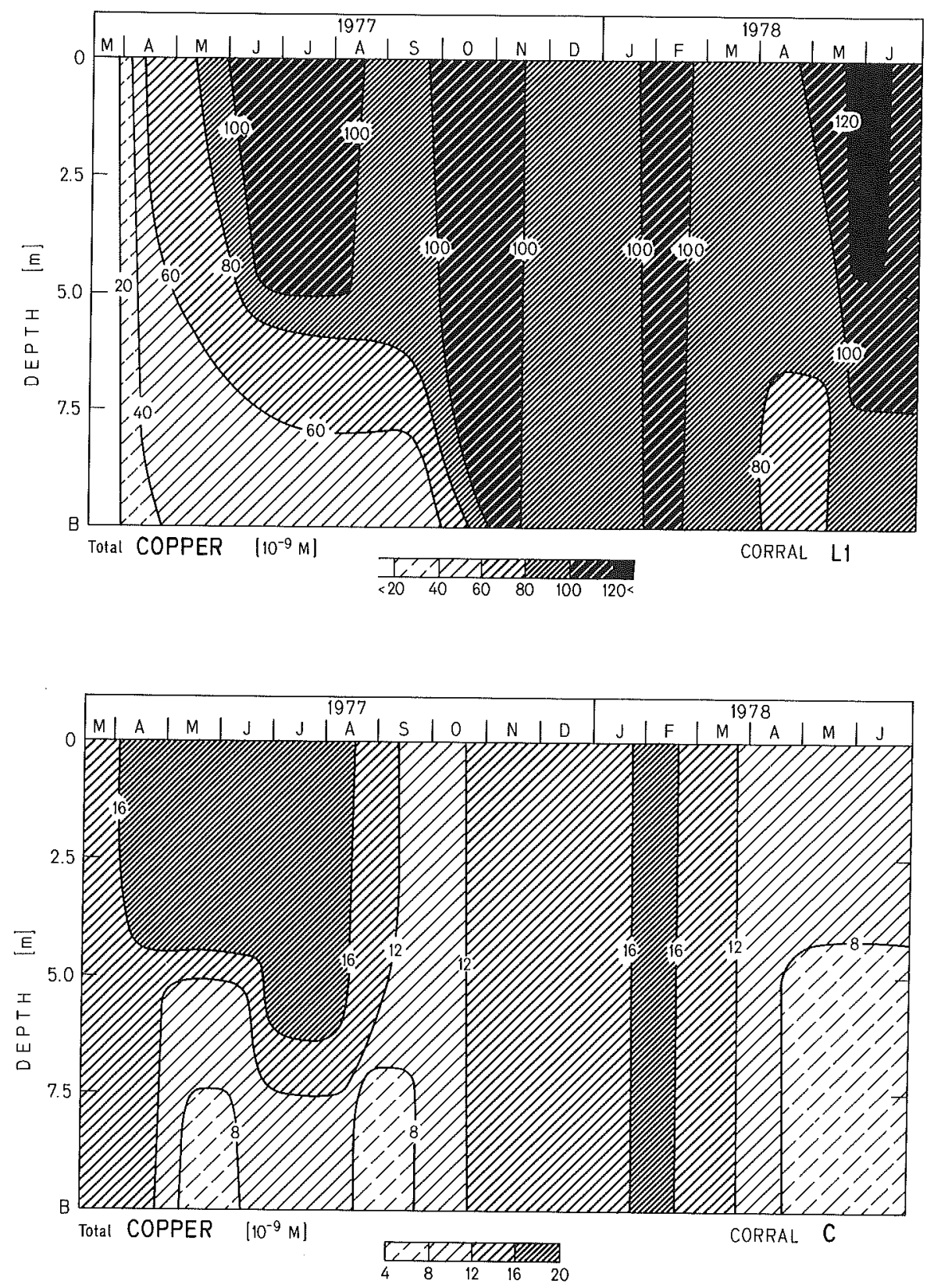

Figure I. Isopleths of total copper of loaded corral LI and control corral C. Abb. I. Isoplethen des totalen Kupfers im belasteten Corral L1 und im Kontroll-Corral C. 

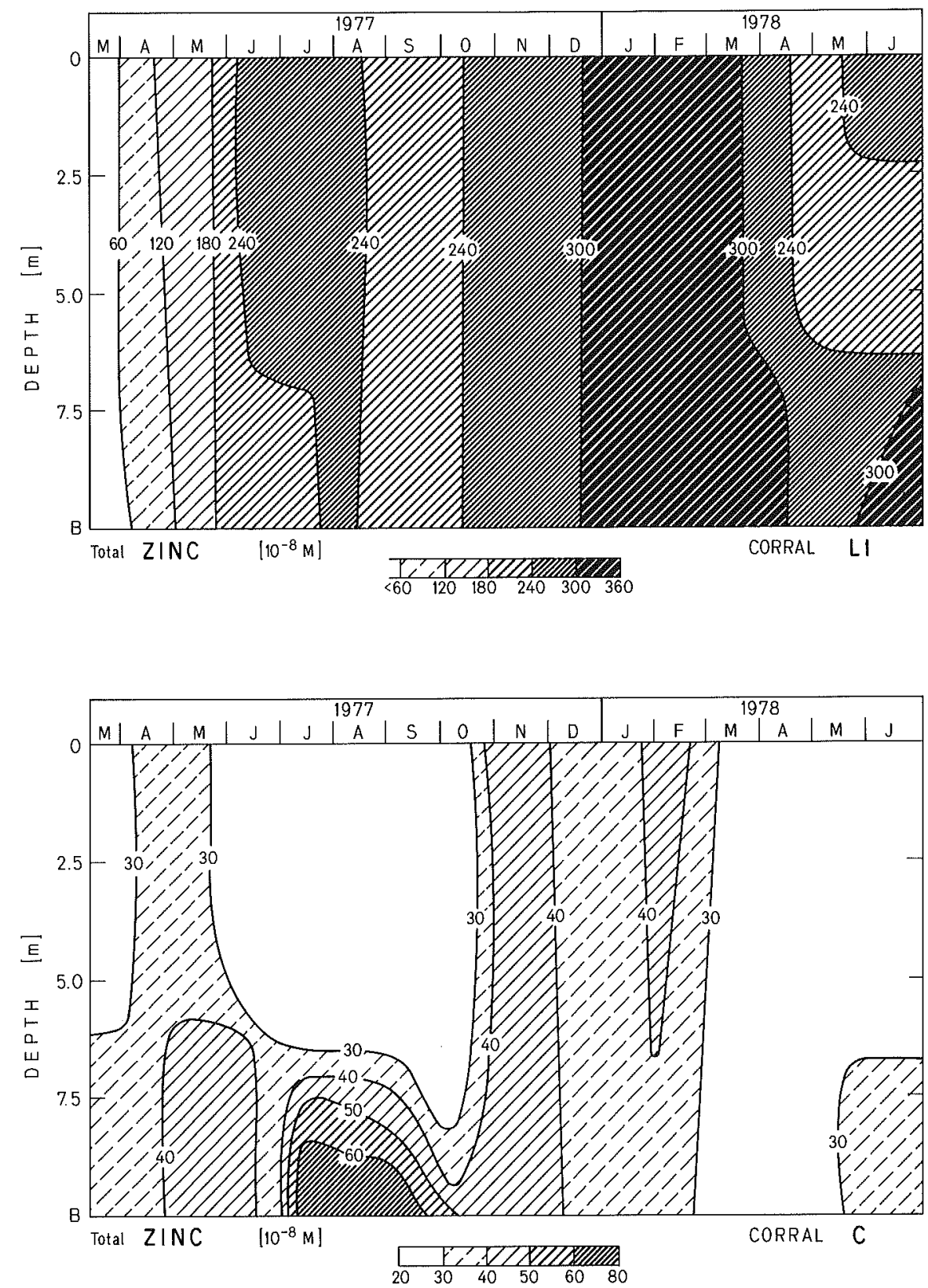

Figure 2. Isopleths of total zinc of loaded corral L1 and control corral C.

Abb.2. Isoplethen des totalen Zinks im belasteten Corral L1 und im Kontroll-Corral C. 
1. Between March and August 1977 the loaded corrals L1 and L2 experience a gradual increase of all five metals, preferentially in the epilimnium $(0-5 \mathrm{~m})$. This phenomenon correlates with the observed stratification of the corrals according to the temperature profiles [8]. Zinc does not show the same behavior. The isopleths of the control corral $\mathrm{C}$ indicate that an additional source is responsible for a synchrone concentration increase in the hypolimnion. A corresponding increase in the epilimnion is much smaller, due to the permanent dilution of incoming water with lower $\mathrm{Zn}$ concentration.

2. In the month of October 1977 the concentration gradients are strongly reduced and until April 1978 all concentration profiles show no vertical gradients. The temperature profiles [8] confirm that the vertical mixing processes start in October 1977 and the new stratification process does not begin before the end of April 1978.

3. During the build up of a new stratification period from April to June 1978 all metals except zinc show a concentration increase in the upper half relative to the lower one. At the end of June 1978 the elements cadmium, mercury and lead show a drastic reduction in the total and, even more pronounced, in the dissolved concentration. This indicates a relatively high percentage of particulate fraction. Again the isopleths of zinc show a concentration increase in the lower half of the corral.

The mercury concentrations in the control corral are below the detection limit of the analytical method (table 1).

In figure 3 the ratio of the mean epilimnic concentration $(0-5 \mathrm{~m})$ to the input

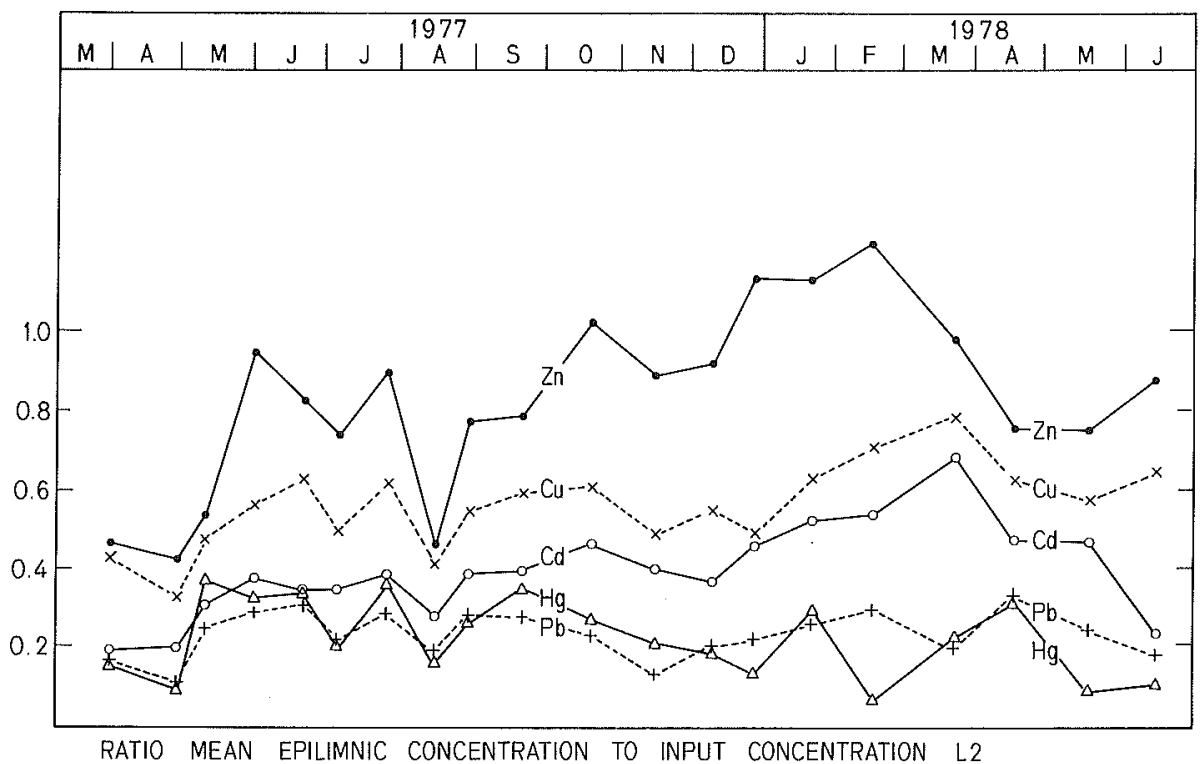

Figure 3. Ratio of mean epilimnic concentration [TM] to concentration $\left[\mathrm{TM}_{\mathrm{i}}\right]$ of the inflow in the loaded corral L2 as a function of time.

Abb.3. Verhältnis der mittleren Epilimniumkonzentration [TM] zur Zuflusskonzentration $\left[\mathrm{TM}_{\mathrm{i}}\right]$ in Funktion der Zeit. 
concentration (see section 3) is shown as a function of time in each interval. In periods of constant input and small fluctuation of the epilimnic concentration this ratio corresponds to the relative residence time $\tau_{M}^{\prime}$ of a metal within the upper half of the corral. The term 'relative residence time' is used as defined by Stumm and Morgan [14] and will be discussed in section 4.3.

According to these ratios the loaded epilimnic systems would impose the following order of residence times:

$$
\mathrm{Zn}>\mathrm{Cu}>\mathrm{Cd}>\mathrm{Pb} \approx \mathrm{Hg} .
$$

\subsection{Metal contents of sediments and periphyton}

\subsection{Freshly sedimented material}

The metal contents of sedimented material, caught in sediment traps at 5 and $10 \mathrm{~m}$, show relative minimum values for all metals in June, July, August 1977 and June 1978. Copper (fig. 4) contents are highest during the months November 1977 to February 1978, whereas all other metals have maximum values in October/November 1977, e.g. lead (fig. 5).

A comparison of the main components of the sedimenting material is made in

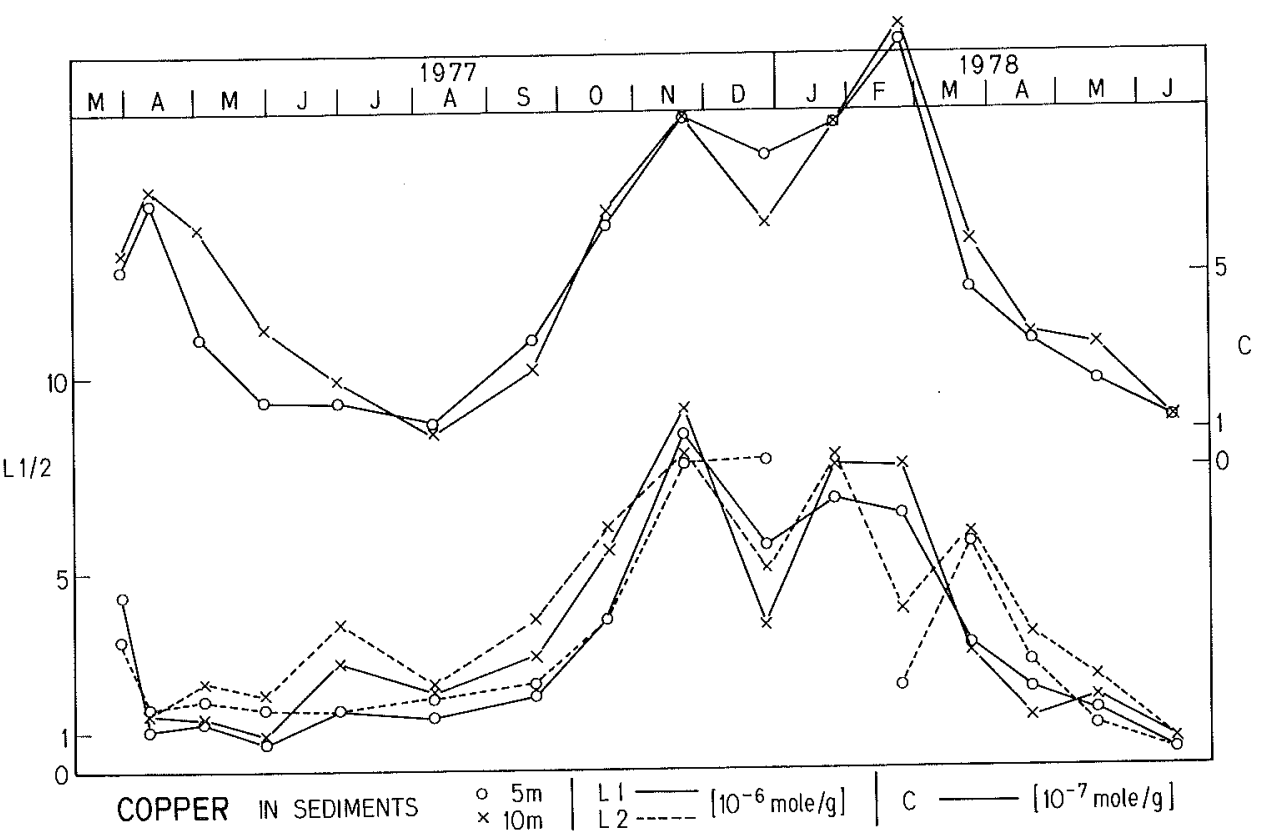

Figure 4. Seasonal variation of copper concentration in dried sedimenting matter (collected in sediment (raps). Concentration scale for the loaded corrals L1 and L2 on the left, for the control corral on the right ordinate.

Abb.4. Zeitliche Veränderung der Kupferkonzentration im getrockneten, sedimentierten Material (aufgefangen in Sedimentpfannen). Die Konzentrationsskala der belasteten Corrals ist auf der linken, die der Kontrolle auf der rechten Ordinate. 
figure 6. Calcium carbonate (calculated from the calcium content) and the organic material (loss on ignition) form the main fractions. This distribution pattern is similar to the one of a natural lake with a very small input of allochthonous material, e.g. Rotsee [9] and Lake Baldegg [10].

\subsection{Periphyton}

The metal contents of the periphyton (table 3 ) are of the same order of magnitude as the ones of the phytoplankton [11]. Furthermore the $\mathrm{Cu}, \mathrm{Zn}$ and $\mathrm{Pb}$ contents are lower in May than in November in the loaded corrals.

\subsection{Metal contents in the surface layers of recent sediments}

The metal contents of surface sediment samples taken along a diameter from north to south (January 1978) at an intermediate distance of $1 \mathrm{~m}$ are shown in figure 7. The thickness of the surface layer is approximately $1 \mathrm{~cm}$. The samples in the northern half show significantly higher concentrations than the southern ones. The variations indicate further that sedimentation is not homogenous in this half of the corrals. The reference values $\mathrm{R}$ are taken from the same cores at a depth of $10 \mathrm{~cm}$ (mean value). They are practically equal to the surface contents of the control

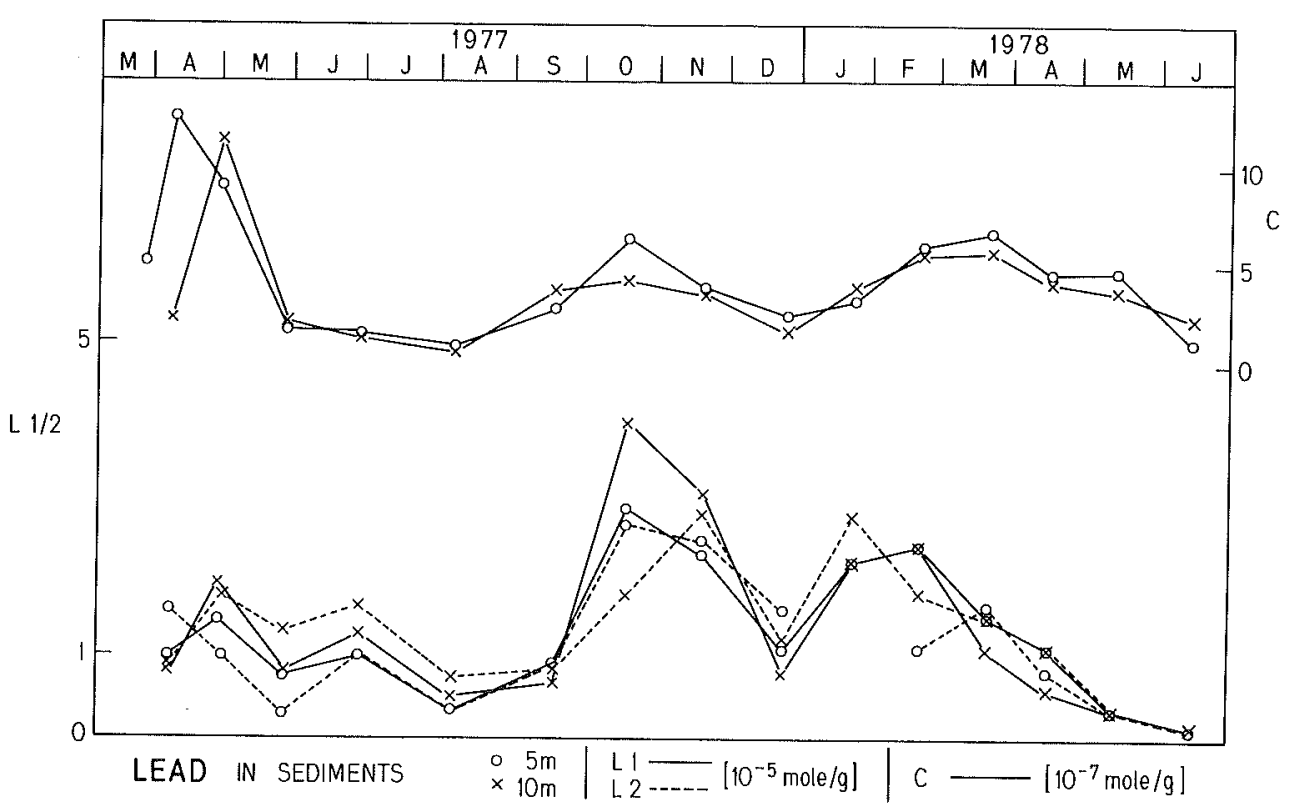

Figure 5. Seasonal variation of lead concentration in dried sedimenting matter (collected in sediment traps). Concentration scale for the loaded corrals $\mathrm{L} 1$ and $\mathrm{L} 2$ on the left, for the control corral on the right ordinate.

Abb.5. Zeitliche Veränderung der Bleikonzentration im getrockneten, sedimentierten Material (aufgefangen in Sedimentpfannen). Dic Konzentrationsskala der belasteten Corrals ist auf der linken, die der Kontrolle auf der rechten Ordinate. 


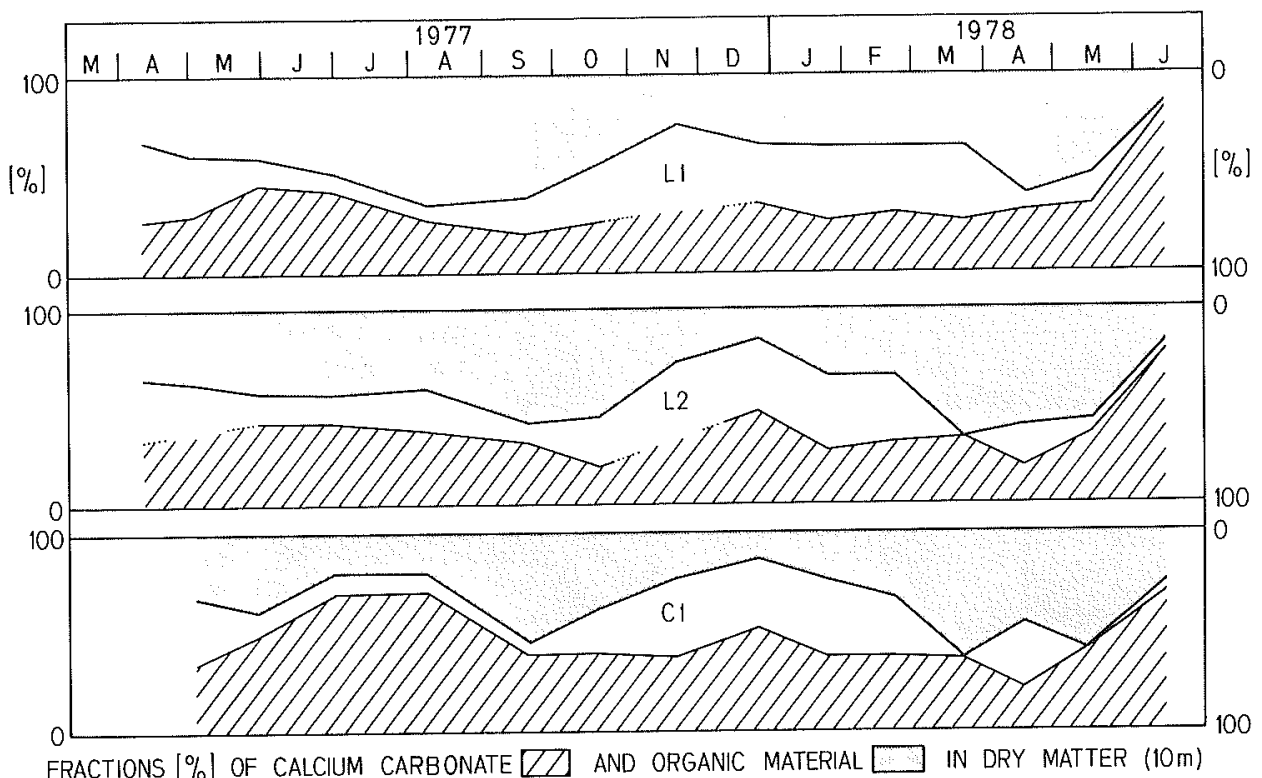

Figure 6. Fractions (\%) of calcium carbonate and organic substances (loss on ignition) in dry matter (collected in sediment traps) as a function of time.

Abb.6. Anteile (\%) von Kalziumkarbonat und organischen Substanzen (als Glühverlust) in der Trockensubstanz (aufgefangen in Sedimentpfannen) in Funktion der Zeit.

Table 3. Metal concentration of periphyton ${ }^{\mathrm{l}}$ ).

Tabelle 3. Metallkonzentrationen im Periphyton ${ }^{\mathrm{I}}$ ).

\begin{tabular}{llcccc}
\hline & \multicolumn{2}{c}{$\left(10^{-8}\right.$ mole/g dry matter $)$} & $\mathrm{Cd}$ & $\mathrm{Hg}$ & $\mathrm{Pb}$ \\
\hline $\mathrm{Cu} 2$ & $\mathrm{Zn}$ & 58 & 2.9 & 640 \\
& 116 & 7,300 & 56 & 3.6 & 380 \\
$\mathrm{C}$ & 55 & 3,000 & 1 & 0.1 & 3 \\
& 14 & 400 & 1 & 0.1 & 14 \\
\hline
\end{tabular}

1) Upper value: November 1977/Oberer Wert: November 1977. Lower value: May 1978/Unterer Wert: Mai 1978.

container, except for copper whose concentration is increasing with greater core depth.

The numerical values of the metal balances are given in figure 8 . The following main characteristics can be ascertained:

1. In the loaded systems sedimentation is only a minor part in the elimination of the metals. The sequence of increasing sedimentation is given by

$$
\mathrm{Zn}<\mathrm{Cu}<\mathrm{Cd}<\mathrm{Hg}<\mathrm{Pb} .
$$

2. A positive sign of the error in figure 8 can result from an additional source, a negative sign indicates probably an additional sink. The control corral experiences 

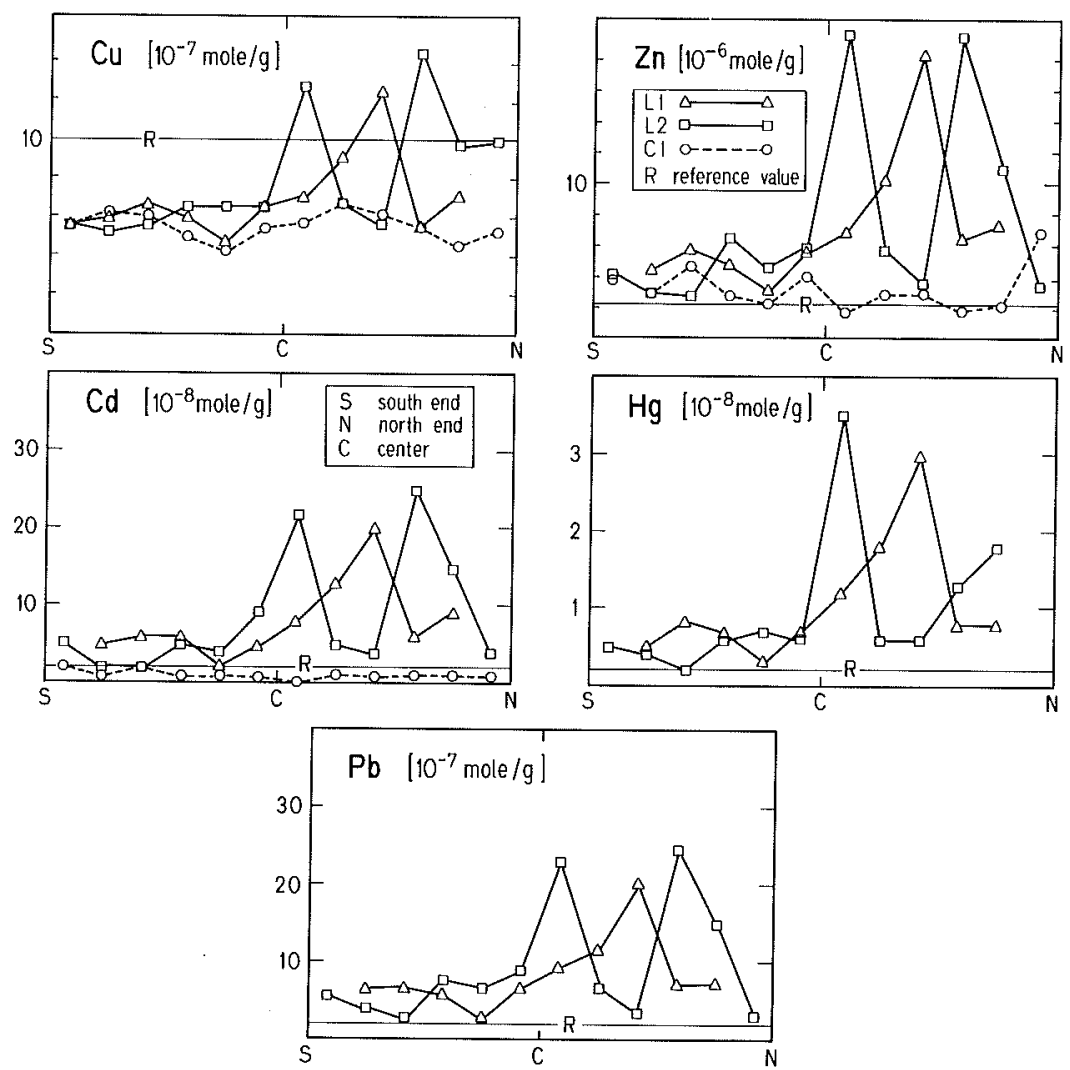

Figure 7. Metal contents in the surface layer $(1 \mathrm{~cm})$ of sediment cores along the diameter of the corral bottom. L1, L2: loaded corrals, C1: control corral.

Abb.7. Metallgehalte in der Oberflächenschicht $(1 \mathrm{~cm})$ von Sedimentkernen entlang dem Nord-Süd-Durchmesser am Corral-Grund. L1, L2: belastete Corrals, C1: Kontroll-Corral.

a relatively high additional source of the metals $\mathrm{Zn}, \mathrm{Cd}$ and $\mathrm{Pb}$. Only in the case of zinc such an additional source could also be observed in the loaded corrals. The balances for the metals $\mathrm{Cu}, \mathrm{Cd}, \mathrm{Hg}$ and $\mathrm{Pb}$ indicate an additional sink in the loaded corrals. The order of increasing negative error is as follows

$$
\mathrm{Cu}<\mathrm{Cd}<\mathrm{Pb}<\mathrm{Hg} .
$$

If one adds the percentages of the two elimination paths within the system, namely sedimentation and error, the order of increasing retention is changed to

$$
\mathrm{Zn}<\mathrm{Cu}<\mathrm{Cd}<\mathrm{Pd}<\mathrm{Hg} .
$$

This is the sequence of the relative residence times already mentioned in section 3.1. From this it can be concluded that additional sources and sinks influence significantly the metal household in the limno-corrals. 


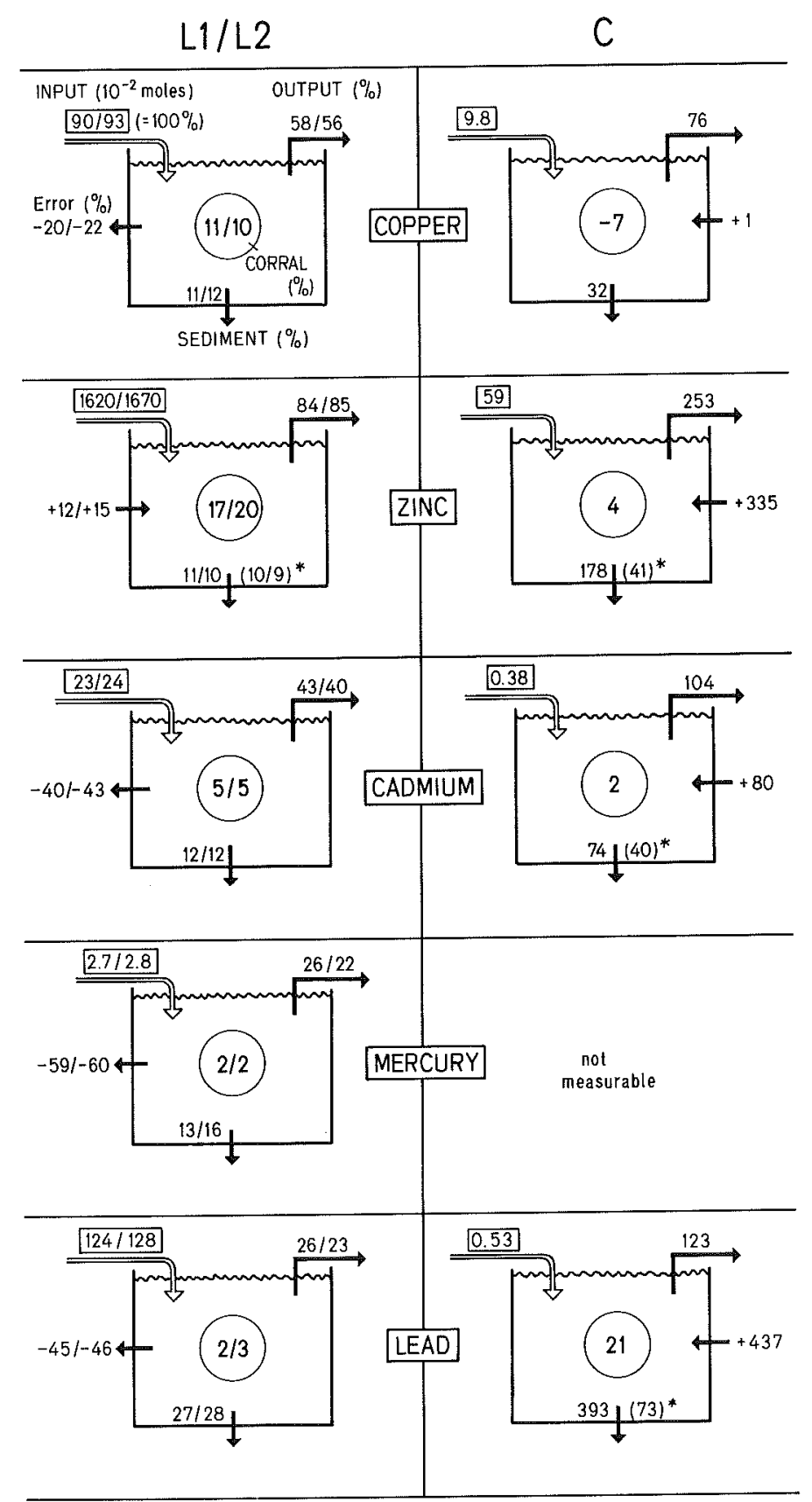

* fraction $(\%)$ corresponding to corrected total input

Figure 8. Metal balances from March 1977 to June 1978. Input in $10^{-2}$ mole. Output, sedimentation, corral, error in percent of input. Input-sedimentation-corral-output + error $=0$. A negative error indicates an additional sink, a positive error an additional source.

Abb. 8. Metallbilanz für die Periode März 1977 bis Juni 1978. Input in $10^{-2}$ Mol. Output, Sedimentation, Cotral, Fehler in Prozenten des Input. Input-Sedimentation-Corral-Output + Fehler=0. Ein negativer Fehler bedeutet eine zusätzliche Senke, ein positiver Fehler eine zusätzliche Quelle. 


\section{Discussion}

\subsection{Evaluation of sinks and sources}

In view of the apparent net loss in the loaded corrals and the apparent additional input in the control (fig. 8) the following question should be asked:

Is the phenomenology of the metal balance primarily due to additional sinks and sources not yet considered (conceptual gaps) or is it a result of random or systematic errors in the analytic data?

\subsection{Discussion of errors}

The error e has been defined in section 2.32 by the metal balance

$$
\mathrm{i}-\mathrm{o}-\Delta \mathrm{c}-\mathrm{s}+\mathrm{e}=0 .
$$

This error $e$ is the sum of all systematic and random errors included in the experimental data and of errors originating from processes which also affect the metal regulation but have not been considered in the balance. It is not possible to separate the various components of e from each other but the structure of the metal balance allows at least to distinguish various groups of errors:

Each of the balance elements $\mathrm{i}$, o and $\mathrm{s}$ is equal to the sum of the twenty values measured for the intervals of the experiment. Thus it can be assumed that the error of these elements would be mainly systematic and that its random component is negligible.

On the other hand the error of $A c$, depending on the difference of the values $c_{20}$ and $c_{0}$ only, is primarily random. Statistical analysis of metal balances calculated for the individual intervals revealed for all metals in all corrals a strong correlation (correlation coefficient $0.60 \leq \mathrm{r} \leq 0.97 ; \mathrm{r}_{99 \%, 20 \text { values }}=0.53$ ) between e and $\Delta \mathrm{c}$ which allowed to estimate the error of $\Delta c$. This error turned out to be twice the value expected from the analytical errors (table 1). Further sources of the error of $\Delta \mathrm{c}$ might be the calculation of c from only five measured values TM (section 2.31) or short oscillations of $\mathrm{c}$, due to the dynamics of biomass, or both.

According to this discussion two components of e can be distinguished:

$$
\mathrm{e}=\mathrm{e}_{\mathrm{s}}+\mathrm{e}_{\mathrm{r}}
$$

The component $e_{s}$ of e includes all the systematic errors of the balance elements $i, o$ and $s$ plus the conceptual errors due to additional sinks and sources. The component $e_{r}$ is formed by the standard deviation of the error of $4 \mathrm{c}$ and can be interpreted as an error limit of $\mathrm{e}_{\mathrm{s}}$.

The numerical values of $e_{s}$ and $e_{r}$ are shown in table 4. A simple control of the reliability of the error limit $e_{r}$ is given by the comparison of $e_{r}$ with the difference between $\mathrm{e}_{\mathrm{s}}(\mathrm{L} 1)$ and $\mathrm{e}_{\mathrm{s}}(\mathrm{L} 2)$. 
Table 4. Additional sinks and sources $\mathrm{e}_{\mathrm{s}}$ of metals with corresponding error limits $\mathrm{e}_{\mathrm{r}}\left(10^{-2}\right.$ mole). Tabelle 4. Zusätzliche Metallsenken und -quellen $e_{s}$ mit entsprechenden Fehlergrenzen $e_{r}\left(10^{-2} \mathrm{Mol}\right)$.

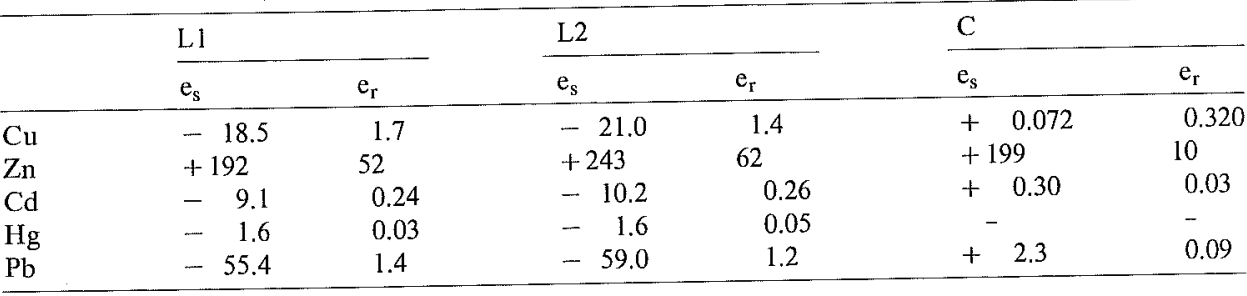

\subsection{Assignment of sinks and sources}

\section{Zinc source}

Table 4 indicates that all three corrals have an additional zinc source which is in the same order of magnitude, namely $(211 \pm 28) 10^{-2} \mathrm{M}$. Laboratory experiments investigating desorption of metals from corral wall material [4] could verify that zinc is dissolved in lake water. The observed quantity in the field experiments corresponds to a mean flux of $1.1 \times 10^{-5} \mathrm{M} \mathrm{m}^{-2} \mathrm{yr}^{-1}$ and is about $25 \%$ of the total zinc present, as $\mathrm{ZnO}$, in the original wall material. This additional source from the walls can explain the different pattern of zinc isopleths in comparison to the other metals (fig. 1,2).

\section{Metal sources in the control corral}

The balances for cadmium and lead show additional sources which cannot be explained by contaminations from the wall. The corresponding value for copper is not significantly different from zero. The analytical program did not include samples from direct precipitation on the corral surface. The order of magnitude of such a contribution can be estimated from earlier measurements in this region [1]. A comparison of this estimation with the observed net sources is given in table 5 . It can be concluded that the contribution by direct precipitation is of the same order of magnitude as the observed net sources for copper (within the error limit) cadmium and lead. For zinc the already mentioned source from the wall is much larger. For the loaded corrals the additional input by precipitation is negligible (compare with fig.8).

Table 5. Comparison of estimated precipitation contribution $(\mathrm{N})$ with additional sources values in corral $\mathrm{C}\left(10^{-2}\right.$ mole $)$.

Tabelle 5. Vergleich der geschätzten Niederschlagsbeiträge (N) mit den zusätzlichen Quellwerten im Kontroll-Corral C $\left(10^{-2} \mathrm{Mol}\right)$.

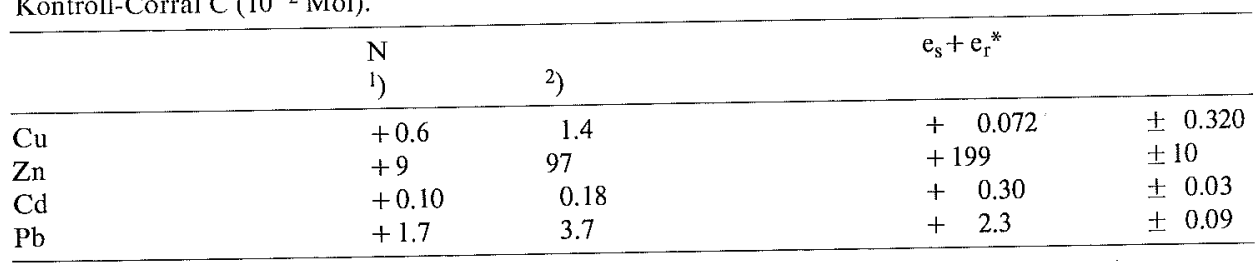

1) Values from Lake Alpnach, 1976 [1].

2) Hydrologisches Jahrbuch, 1976, Station Hausen am Albis.

* Values from table 4. 
Additional sinks in the loaded corrals

All metal balances, except those for zinc, show a deficit in the loaded corrals (table 4). Six possibilities can be stated to explain such a phenomenon

1. a reduced input because of an erroneous dosage performance,

2. an increased output because of an erroneous pump performance in the effluent,

3. leaky corral walls,

4. the sedimentation measured in the traps is far below the mean sedimentation in the corrals,

5. the sediment surface is adsorbing directly from the dissolved phase,

6. the biomass growing on the wall is adsorbing continually from the dissolved phase.

Analytical and technical controls during the experiment exclude the possibilities 1 and 2. An undetected leak would cause a ratio of the error to the mean dissolved concentration to be equal for all metals. The observed values of $e_{S} /\left(D_{L}-D_{L}\right)$ $\left[\begin{array}{ll}10^{6} & 1\end{array}\right]$ are significantly different, namely for $\mathrm{Cu}=2.6, \mathrm{Cd}=3.9$ and $\mathrm{Pb}=21.0$. Therefore possibility 3 can also be excluded. In section 4.11 the random component of the error of the balance element $s$ was said to be negligible what is confirmed by the good correspondence between the independently measured sedimentation values of $L 1$ and $L 2$. Therefore a possible error of $\mathrm{s}$ can be assumed to be a systematic one, possible deficits due to underestimated sedimentation would be expected to show the same relative proportions as the measured s values. However the measured sequence of relative elimination by sedimentation (fig. 8) is not in agreement with such a hypothesis:

$$
\mathrm{Cu}(10-11 \%) \leq \mathrm{Cd}(12 \%)<\mathrm{Hg}(13-16 \%)<\mathrm{Pb}(27-28 \%) .
$$

The velocity of direct adsorption by the sediment surface depends also from the velocity of vertical Eddy diffusion. During the period of stratification (June 1977 to September 1977) such a process is described by the diffusion coefficient of the thermocline $\mathrm{k}_{\mathrm{z}}=5 \cdot 10^{-2} \mathrm{~cm}^{2} \mathrm{sec}^{-1}$ [8]. The calculated fluxes between a depth of $5 \mathrm{~m}$ and $7.5 \mathrm{~m}$ are not high enough $\left[30-50 \%\right.$ of the mean deficit fluxes $\left(\right.$ mole $\left.\left.\mathrm{m}^{-2} \mathrm{~d}^{-1}\right)\right]$ to explain the necessary first transport step from the epilimnion into the hypolimnion. In addition the observed small diffusion near the bottom, characterized by the coefficient $\mathrm{k}_{\mathrm{z}}=2.10^{-3} \mathrm{~cm}^{2} \mathrm{sec}^{-1}$ [8], prevents the sediment surface from directly adsorbing a significant quantity of the metal present in the dissolved phase. It follows that an additional sink must be located in the epilimnic compartment $(0-5 \mathrm{~m})$. The experimental observation that the metal contents in the biomass growing on the corral walls (table 3 ) are of the same order of magnitude as those determined in the plankton leads to the following hypothesis:

The periphyton production and its assimilation of metals are in the same order of magnitude as the corresponding parameters of the plankton. In contrast to the plankton the dying fractions falling from the wall are not distributed homogeneously within the corral and cannot be caught in the sediment traps. This hypothesis is supported by two observations: 
1. According to Müller [13] the epilithic primary production between 0 and $5 \mathrm{~m}$ (Greifensee) is in the same order of magnitude as the primary production of phytoplankton in the corresponding water volume. The surface to volume ratio in the investigated littoral region is approximately $1 \mathrm{~m}^{-1}$, i.e. in the same order of magnitude as the one in the MELIMEX corral, namely $0.3 \mathrm{~m}^{-1}$.

2. The variation of metal concentration in sediment surfaces along a corral diameter (fig. 7) indicates a nonhomogeneous distribution of sedimented material.

In conclusion the epilimnion of the corrals in the MELIMEX experiment resembles a littoral zone of a natural lake.

\subsection{Evaluation of chemical and biological factors determining the elimination processes}

According to the overall metal balance (fig. 8) and the conclusions of section 4.1, the model lakes have two internal elimination paths to reduce the input concentration of metals, namely by adsorption on the walls and by particularization in the water column. The latter process can be caused by chemical precipitation and by assimilation of the plankton which is finally sedimented.

\subsection{Chemical precipitation}

The lack of sufficient knowledge about the chemical speciation of the trace metals in fresh waters prevents a detailed analysis of the solubility conditions. Nevertheless, one can estimate the conditional solubility products [14] for known inorganic salts which could be formed under the chosen experimental conditions. For a comparison the conditional solubility products of the carbonates of $\mathrm{Zn}, \mathrm{Cd}$ and $\mathrm{Pb}$ are investigated. For $\mathrm{Zn}$ the formations of hydrozincite and hydroxide are included. Copper is discussed separately [15]. The selection of these species is based on previous estimations presented by different authors [16, 17].

The solubility products are defined as follows:

Metal carbonate $\mathrm{MCO}_{3}(\mathrm{MC})$ :

$$
\mathrm{pP}_{(\mathrm{MC})}=\log \mathrm{K}_{\mathrm{so}(\mathrm{MC})}+2 \mathrm{pH}+\log \alpha_{\mathrm{M}}+\log \alpha_{0} .
$$

Hydrozincite $\mathrm{Zn}_{5}(\mathrm{OH})_{6}\left(\mathrm{CO}_{3}\right)_{2}(\mathrm{HZ})$ :

$$
\mathrm{pP}_{(\mathrm{HZ})}=\log \mathrm{K}_{\mathrm{so}(\mathrm{HZ})}+2 \mathrm{pH}+\log a_{\mathrm{Zn}}+0.4 \log \alpha_{0}
$$

where $\mathrm{K}_{\mathrm{so}}$ are the solubility products $\left(\mathrm{I}=0.2,25^{\circ} \mathrm{C}\right)$,

$$
\begin{aligned}
& a_{\mathrm{M}}=\frac{\left[\mathrm{M}^{2+}(\mathrm{aq})\right]}{\left[\mathrm{M}_{\mathrm{tot}}\right]} \quad \text { (considering the hydroxospecies formed), } \\
& a_{0}=\frac{\left[\mathrm{H}_{2} \mathrm{CO}_{3}\right]}{\left[\mathrm{CO}_{3 \text { tot }}\right]} .
\end{aligned}
$$


During the experimental period the $\mathrm{pH}$ varied between 7.6 and 9.2 [15]. The range of $\mathrm{pH} \approx 9$, the relatively most favorable condition for the formation of carbonates and hydroxides, is only observed in the epilimnion for about 2 to 3 months. The results are summarized in table 6. A state of oversaturation or precipitation is reached if $\mathrm{pO}<\mathrm{pP}$. This is only the case for $\mathrm{ZnCO}_{3}$ in $\mathrm{L}$ and $\mathrm{Zn}(\mathrm{OH})_{2}$ in $\mathrm{L}$ and C. However a large difference between $\mathrm{pP}$ and $\mathrm{pO}$ is only estimated for $\mathrm{Zn}(\mathrm{OH})_{2}$ in $L$ (1.8). Therefore a contribution to the sedimentation of zinc by chemical precipitation is possible in the loaded corrals. This contribution depends on two factors, namely the rate of formation and the particle size, about which no informations exists.

Table 6. Conditional solubility products $\mathrm{pP}$ of inorganic salts of zinc, cadmium and lead in comparison to the observed concentration products $\mathrm{pO}$.

Tabelle 6. Konditionelle Löslichkeitsprodukte pP anorganischer Salze von Zink, Cadmium und Blei im Vergleich zu beobachteten Konzentrationsprodukten pO.

\begin{tabular}{lrrr}
\hline & $\mathrm{pP}$ & $\mathrm{pO}$ & \\
\cline { 3 - 4 } & & $\mathrm{L}$ & $\mathrm{C}$ \\
\hline $\mathrm{ZnCO}$ & & 8.1 & 9.5 \\
$\mathrm{Zn}(\mathrm{OH})_{6}\left(\mathrm{CO}_{3}\right)_{2}$ & 8.5 & 6.5 & 8.0 \\
$\mathrm{Zn}(\mathrm{OH})_{2}$ & 5.9 & 15.5 & 17.0 \\
$\mathrm{CdCO}_{3}$ & 17.3 & 9.9 & 11.7 \\
$\mathrm{PbCO}_{3}$ & 8.8 & 9.1 & 10.8 \\
\hline
\end{tabular}

$\mathrm{pH}=9.0, \mathrm{CO}_{3 \text { tot }}=3 \times 10^{-3}$.

From the metal balances one can postulate that direct chemical precipitation cannot be of major importance for all metals because the loaded corrals show a significantly lower percentage in sedimentation than the control (fig. 8). An elimination mechanism, which is primarily based on chemical precipitation, should show the opposite phenomenon.

A second possibility is the adsorption of metals in inorganic particles formed in the corrals, e.g. as calcium carbonate. A scavenging effect of sedimenting $\mathrm{CaCO}_{3}$ should be detectable in the metal concentrations of the collected material in the traps (fig. 4, 5). In a period of high $\mathrm{CaCO}_{3}$ contents, e.g. May/June 1978 (fig. 6), all metal concentrations are significantly decreased which indicates that such a process cannot be important.

\subsection{Biogenic precipitation}

In order to estimate the contribution of biomass to the metal sedimentation the following simplifications are introduced:

a) The phytoplankton is mainly responsible for the formation of particulate metals. According to Gächter [11] the zooplankton has a much smaller metal content than the phytoplankton. More than $90 \%$ of the metal taken up by ingestion must be excreted again. Therefore the zooplankton's net contribution to particularization is negligible.

b) The rate of adsorption of metals by the phytoplankton is much faster than 
the rate of sedimentation. In a first approximation the distribution of metal between the biomass and the aquatic medium can be described with a constant $\mathrm{D}_{\mathrm{M}}$, named distribution coefficient:

$$
\mathrm{D}_{\mathrm{M}}=\frac{[\mathrm{BM}]}{[\mathrm{DM}]} \quad\left(\mathrm{m}^{3} \mathrm{~kg}^{-1}\right)
$$

whereas $[B M]$ is expressed in mole/kg dry matter and [DM] in mole $\mathrm{m}^{-3}$. Different authors have shown that such a distribution coefficient depends on the plankton species and the chemical speciation of the metal in the medium [19-21]. Two information sources are available to estimate mean values for $D_{M}$, namely the metal concentrations of phytoplankton species with diameters between 25 and $300 \mu \mathrm{m} \mathrm{[11]} \mathrm{and} \mathrm{the} \mathrm{metal} \mathrm{concentrations} \mathrm{of} \mathrm{the} \mathrm{sedimented} \mathrm{material} \mathrm{in} \mathrm{the} \mathrm{traps}$ (exemplified in 4.5). The latter values have to be related to the non-calcium carbonate fraction considering the conclusion in 4.21 . The $\mathrm{D}_{\mathrm{M}}$ values are compared in table 7. Mercury is not considered because of the relatively high errors in the values of the dissolved fraction. The same holds for lead in the control. For $\mathrm{Cu}$, $\mathrm{Zn}$ and $\mathrm{Cd}$ in the sediment and in the phytoplankton the distribution coefficients of the control are higher than those in the loaded corrals. The periphyton does not show a significant difference. The $\mathrm{D}_{\mathrm{M}}$ values for sediments are also higher than the ones for the phytoplankton. This must be due to the fact that plankton sampling excludes all species which are smaller than about $25 \mu \mathrm{m}$. However the smaller sized plankton has a higher 'adsorbing surface per mass unit' which can lead to higher metal concentrations. Therefore the $D_{M}$ values of the sediment would be a better estimate for the total biomass.

Table 7. Mean distribution coefficients $\overline{\mathrm{D}_{\mathrm{M}}}\left(10^{2} \mathrm{~m}^{3} \mathrm{~kg}^{-1}\right)$ for the period between June 1977 and June 1978. $\mathrm{PH}=$ phytoplankton, $\mathrm{W}=$ periphyton, $\mathrm{OF}=$ organic fraction of the sediment, ( ) number of samples.

Tabelle 7. Mittlere Verteilungskoeffizienten $\overline{D_{M}}\left(10^{2} \mathrm{~m}^{3} \mathrm{~kg}^{-1}\right)$ für die Zeit von Juni 1977 bis Juni 1978. $\mathrm{PH}=$ Phytoplankton, $\mathrm{W}=$ Periphyton, $\mathrm{OF}=$ organische Fraktion im Sediment, ( ) Zahl der Proben.

\begin{tabular}{|c|c|c|c|c|c|c|}
\hline \multirow{2}{*}{$\begin{array}{l}\text { Corral samples } \\
\text { Metal }\end{array}$} & \multicolumn{3}{|l|}{$\mathrm{L}$} & \multicolumn{3}{|l|}{$\mathrm{C}$} \\
\hline & $\begin{array}{l}\text { PH } \\
(20-30)\end{array}$ & $\begin{array}{l}\text { OF } \\
(22)\end{array}$ & $\begin{array}{l}\text { W } \\
(4)\end{array}$ & $\begin{array}{l}\mathrm{PH} \\
(15-20)\end{array}$ & $\begin{array}{l}\text { OF } \\
(11)\end{array}$ & $\begin{array}{l}\text { W } \\
(4) \\
\end{array}$ \\
\hline $\mathrm{Cu}$ & 0.30 & 0.55 & 0.1 & 0.77 & 0.71 & 0.1 \\
\hline $\mathrm{Zn}$ & 0.17 & 0.30 & 0.2 & 0.89 & 1.3 & 0.2 \\
\hline $\mathrm{Cd}$ & 0.35 & 0.70 & 0.3 & 1.0 & 1.4 & 0.1 \\
\hline $\mathrm{Pb}$ & 2.0 & 7.9 & 1.5 & - & - & - \\
\hline
\end{tabular}

c) As a measure for the concentration of biomass present in the water column and in the sedimented material the parameters 'particulate organic nitrogen' [PN] and 'Kjeldahl nitrogen of dry matter' [SN], respectively, are employed. The mean sedimentation rate $\sigma$ of biomass can be estimated according to

$$
\sigma=\frac{[\overline{\mathrm{SN}}]}{[\overline{\mathrm{PN}}]} \quad\left(\mathrm{md}^{-1}\right)
$$


whereas $[\overline{\mathrm{SN}}]$ is the mean sedimentation rate of Kjeldahl nitrogen expressed in $\mathrm{mg} \mathrm{m} \mathrm{d}^{-1}$ and $[\mathrm{PN}]$ is the mean particulate Kjeldahl nitrogen in the hypolimnion expressed in $\mathrm{mg} \mathrm{m}^{-3}$. Since the distribution coefficient $\mathrm{D}$ is related to the dry matter of biomass the parameter $[\overline{\mathrm{PN}}]$ can be substituted by $[\mathrm{P}]\left(\mathrm{kg} \mathrm{m}^{-3}\right)$ using the approximation found by Bundi [22] for lake water plankton, namely $1 \mathrm{mg}$ dry matter per $90 \mu \mathrm{g}$ PN. The results of this estimation are summarized in table 8 . The $[\overline{\mathrm{SN}}]$ values reflect the fact that the control corral has a higher biomass production than the loaded ones, as observed by Gächter [12]. The difference in sedimentation rate $\sigma$ might be due to the different composition of plankton species in $\mathrm{L}$ and $\mathrm{C}[12]$.

Table 8. Estimated sedimentation rate $\sigma\left(\mathrm{m} \mathrm{d}^{-1}\right)$ of biomass in the period from June 1977 to June 1978. $[\overline{\mathrm{SN}}]=$ mean sedimentation of Kjeldahl nitrogen $\left(\mathrm{mg} \mathrm{m}^{-2} \mathrm{~d}^{-1}\right),[\overline{\mathrm{PN}}]=$ mean concentration of particulate Kjeldahl nitrogen $\left(\mathrm{mgm}^{-3}\right),[\mathrm{P}]=$ mean concentration of biomass particles as dry matter $\left(10^{-3} \mathrm{kgm}^{-3}\right)$. Tabelle 8. Geschätzte Sedimentationsgeschwindigkeit $\sigma\left(\mathrm{m} \mathrm{d}^{-1}\right)$ der Biomasse in der Zeit von Juni 1977 bis Juni 1978.

$(\overline{\mathrm{SN}})=$ mittlere Sedimentation des Kjeldahl-Stickstoffes $\left(\mathrm{mg} \mathrm{m}^{-2} \mathrm{~d}^{-1}\right) \cdot[\overline{\mathrm{PN}}]=$ mittlere Konzentration des partikulären Kjeldahl-Stickstoffes $\left(\mathrm{mg} \mathrm{m}^{-3}\right)$. $[\mathrm{P}]=$ mittlere Konzentration der Biomassepartikel, angegeben als Trockensubstanz $\left(10^{-3} \mathrm{~kg} \mathrm{~m}^{-3}\right)$.

\begin{tabular}{lcc}
\hline & $\mathrm{L}$ & $\mathrm{C}$ \\
\hline$\overline{[\mathrm{SN}}]$ & 23 & 58 \\
{$[\overline{\mathrm{PN}}]$} & 120 & 190 \\
{$[\overline{\mathrm{P}}]$} & 1.4 & 2.1 \\
$\sigma$ & 0.2 & 0.3 \\
\hline
\end{tabular}

Considering all the above mentioned approximations the contribution of planktonic biomass to the total sedimentation $\mathrm{s}_{\mathrm{M}}$ (mole) of metals can be estimated as follows:

$$
\mathrm{s}_{\mathrm{M}}=\overline{[\mathrm{P}]}\left[\overline{\mathrm{D}_{\mathrm{M}}}\right][\overline{\mathrm{DM}}] \sigma \mathrm{F} \Delta \mathrm{t}
$$

where $F$ is the surface area of the corral $\left(\mathrm{m}^{2}\right), \Delta t$ the time of the observation period (d).

In table 9 the result of this estimate is compared with the measured sedimented quantity given in the metal balance. This comparison leads to the conclusion that

Table 9. Sedimentation of metals by planktonic biomass, comparison of calculated with measured quantities. Observation period: L (June 1977 to Juni 1978), C (March 1977 to June 1978), S (mole/observation period).

Tabelle 9. Metallsedimentation durch das Plankton. Vergleich berechneter und gemessener Mengen.

\begin{tabular}{llllll}
\hline $\mathrm{S}$ & $\mathrm{L}$ & & \multicolumn{2}{c}{$\mathrm{C}$} & \\
\cline { 2 - 3 } $\mathrm{M}$ & S calc. & S obs. & & S calc. & S obs. \\
\hline $\mathrm{Cu}$ & 0.056 & 0.087 & & 0.031 & 0.031 \\
$\mathrm{Zn}$ & 0.81 & 0.95 & & 0.82 & $1 . \mathrm{I}$ \\
$\mathrm{Cd}$ & 0.014 & 0.017 & & 0.0032 & 0.0028 \\
$\mathrm{~Pb}$ & 0.32 & 0.29 & - & 0.021 \\
\hline
\end{tabular}


the particularization of metals by the planktonic biomass must be the dominant factor in the sedimentation of these elements. Furthermore it can be explained why the control corral shows a relatively higher elimination by sedimentation than the loaded ones (fig. 8). The control corral has a higher biomass production, a phytoplankton with a higher metal assimilation $\left(\mathrm{D}_{\mathrm{M}}\right.$ in table 7 ) and a higher sedimentation rate. It follows from this that the metal load chosen in the MELIMEX experiment reduces the system's capacity to lower the metal concentration.

\subsection{A steady-state model for the regulation of heavy metal concentrations in the limno-corrals}

The metal flux to a natural lake can be divided operationally into two physical states, namely the particulate and the dissolved one. It has been shown earlier [1] that the particulate allochthonous forms are sedimented almost quantitatively without any additional adsorption which could reduce the dissolved concentration within the lake. Within relatively broad limits this fraction can hardly influence the assimilation of heavy metals [18]. It is obvious that the dissolved fraction furnishes the heavy metal reservoir from which the primary producers assimilate the optimal, toxic or even lethal quantities. It is the same biosphere which possesses the system's capacity to reduce the concentration of this reservoir.

The removal of dissolved matter can be described with a steady-state model if the input is approximately balanced by the output resulting in an almost constant quantity within the system during a longer period of time. This condition is practically fulfilled for the loaded corrals from June 1977 to June 1978 and the control for the whole experimental period (see section 4.11).

The principles of the steady-state description for limnic systems are discussed by Imboden and Lerman [24]. Schindler [25] has developed an one-box model for trace metal steady-state concentrations in natural systems using an inorganic adsorption mechanism.

The steady state of limno-corrals can be described with the following set of equations (all concentrations are defined as mean concentrations):

$$
\frac{\mathrm{d}(\mathrm{c})}{\mathrm{dt}}=\left[\mathrm{TM}_{\mathrm{i}}\right] \mathrm{Q}_{\mathrm{i}}-[\mathrm{PM}] \mathrm{Q}_{\mathrm{s}}-[\mathrm{TM}] \mathrm{Q}_{\mathrm{o}}-\mathrm{W}_{\mathrm{M}}=0
$$

where

$\left[\mathrm{TM}_{\mathrm{i}}\right] \quad$ Concentration of total metal in the inflow $\left(\right.$ mole $\left.\mathrm{m}^{-3}\right)$

[TM] Concentration of total metal in the corral $\left(\right.$ mole $\left.^{-3}\right)$

[PM] Concentration of particulate metal in the corral $\left(\mathrm{mole} \mathrm{m}^{-3}\right)$

$\mathrm{Q}_{\mathrm{i}}=\mathrm{Q}_{\mathrm{o}}=\mathrm{Q}$ Rate $\left(\mathrm{m}^{3} \mathrm{~d}^{-1}\right)$ of inflow and outflow $\left(=11.5 \mathrm{~m}^{3} \mathrm{~d}^{-1}\right)$

$\mathrm{Q}_{\mathrm{s}} \quad$ Rate of sedimentation $\left(\mathrm{m}^{3} \mathrm{~d}^{-1}\right)\left(=\sigma \times 113 \mathrm{~m}^{2}\right)$ (table 8)

$\mathrm{W}_{\mathrm{M}} \quad$ Rate of adsorption of metal $\mathrm{M}$ at the wall (mole $\mathrm{d}^{-1}$ ) 
$[\mathrm{PM}]=[\mathrm{P}] \mathrm{D}_{\mathrm{M}}[\mathrm{DM}]$

where

[P] Concentration of biomass $\left(\mathrm{kg} \mathrm{m}^{-3}\right.$ dry matter)

$D_{M} \quad$ Distribution coefficient of biomass for the metal $\mathrm{M}\left(\mathrm{m}^{3} \mathrm{~kg}^{-1}\right)$

[DM] Concentration of dissolved metal in the corral $\left(\right.$ mole $\left.\mathrm{m}^{-3}\right)$

$$
\underline{\mathrm{TM}}]=[\mathrm{DM}]+[\mathrm{PM}],
$$

$$
\tau_{\mathrm{M}}^{\prime}=\tau_{\mathrm{M}} \times \frac{1}{\tau_{\mathrm{H}_{2} \mathrm{O}}}=\frac{\mathrm{V}[\mathrm{TM}]}{\mathrm{Q}\left[\mathrm{TM}_{\mathrm{i}}\right]} \times \frac{\mathrm{Q}}{\mathrm{V}}=\frac{[\mathrm{TM}]}{\underline{\left[\mathrm{TM}_{\mathrm{i}}\right]}} .
$$

$\tau_{M}^{\prime}$ is defined as the relative residence time of the metal $M$ and is thus a measure of the system's capacity to reduce the inflow concentration of the metal M.

From eq. (1) it follows:

$$
\left[\mathrm{TM}_{\mathrm{i}}\right]=\frac{[\mathrm{PM}] \mathrm{Q}_{\mathrm{s}}+\mathrm{W}_{\mathrm{M}}}{\mathrm{Q}}+[\mathrm{TM}] \text {. }
$$

Inserting eq. (1 a), (2) and (3) in (4) gives:

$$
\tau_{M}^{\prime}=\frac{[P] D_{M}+1}{\left(\frac{Q_{s}}{Q}+1\right)[P] D_{M}+\frac{W_{M}}{Q[D M]}+1}
$$

According to eq. (5) the relative residence time $\tau_{M}^{\prime}$ is a function of the hydraulic parameter $Q$, the rate of sedimentation $Q_{s}$, the concentration of the planktonic biomass $[\mathrm{P}]$ (table 8 ) and its distribution coefficient $\mathrm{D}_{\mathrm{M}}$ (table 7 ) the concentration of the dissolved metal (DM) and the rate of adsorption at the wall $\mathrm{W}_{\mathrm{M}}$.

The parameters $\mathrm{W}_{\mathrm{M}}$ for the loaded corrals can be calculated from table 4 . The values are adapted to the discussed observation period (June 1977 to June 1978) and divided by the number of days. For the control corral the parameter $\mathrm{W}_{\mathrm{M}}$ can only be estimated since the metal balance gives only the net source due to atmospheric fallout. It is therefore assumed that the percentage of the inflow adsorbed at the wall is of the same order of magnitude as in the loaded corrals. The assumption is based a two observations, namely the similar distribution coefficients $D_{M}$ (table 7) and the similar production of the periphyton.

The values of $\tau_{M}^{\prime}$ calculated with eq. (5) are compared with the observed $\tau_{M}^{\prime}$ values according to eq. (4). The mean ratio of $[\mathrm{TM}] /\left[\mathrm{TM}_{\mathrm{i}}\right]$ for the epimilimnion of the limno-corrals can be drawn from figure 3. The comparison is summarized in table 10 .

It can be seen that the steady-state model considering only hydraulic and biomass parameters gives the same sequence of the system's ability to regulate the concentration of $\mathrm{Cu}, \mathrm{Zn}, \mathrm{Cd}$ and $\mathrm{Pb}$. The comparison between the loaded and the unloaded systems indicates that the retention ability of the loaded corrals is 
Table 10. Comparison of calculated and observed relative residence times of trace metals.

Tabelle 10. Vergleich der berechneten und beobachteten relativen Aufenthaltszeiten der Metalle.

\begin{tabular}{|c|c|c|c|c|}
\hline & \multicolumn{2}{|l|}{$\mathrm{L}$} & \multicolumn{2}{|l|}{$\mathrm{C}$} \\
\hline & $\tau_{M}^{\prime}$ calc. & $\tau_{\mathrm{M}}^{\prime}$ obs. & $\tau_{M}^{\prime}$ calc. & $\tau_{M}^{\prime}$ obs. \\
\hline $\mathrm{Cu}$ & 0.67 & 0.60 & 0.61 & 0.63 \\
\hline $\mathrm{Zn}$ & 0.93 & 0.84 & 0.62 & 0.56 \\
\hline $\mathrm{Cd}$ & 0.46 & 0.45 & 0.50 & 0.46 \\
\hline $\mathrm{Pb}$ & 0.30 & 0.27 & - & 0.24 \\
\hline
\end{tabular}

primarily maintained because of the adsorption at the wall. The phytoplankton alone would lead to higher residence times. This situation resembles more likely a natural lake in which the contribution of epilithic production is negligible (table 11).

Table 11. Comparison of relative residence times considering phytoplankton only as regulating factor. Tabelle 11. Vergleich der relativen Aufenthaltszeiten der Metalle für den Fall, dass einzig das Phytoplankton regulierend wirkt.

\begin{tabular}{lll} 
& L & C \\
& $\tau_{\mathrm{M}}^{\prime}$ & $\tau_{\mathrm{M}}^{\prime}$ \\
\hline $\mathrm{Cu}$ & 0.89 & 0.72 \\
$\mathrm{Zn}$ & 0.93 & 0.62 \\
$\mathrm{Cd}$ & 0.86 & 0.60 \\
$\mathrm{~Pb}$ & 0.52 & - \\
\hline
\end{tabular}

\section{Summary}

Three limno-corrals of $10 \mathrm{~m}$ depth and a volume of $1,130 \mathrm{~m}^{3}$ were used as model lakes to study the transport paths of the trace metals copper, zinc, cadmium, mercury and lead. The inflow concentrations of two corrals were increased artificially to values which are tolerated by Swiss law. The third corral served as control.

The analysis of the metal balances (fig. 8) for a period of 15 months lead to the conclusion that two main factors are responsible for the internal removal of the trace metals, namely the phytoplankton and the periphyton.

The regulation of the trace metal concentration in the lake can be described with a steady-state model [eq. (5)] in which the properties of the biomass are qualified with a distribution coefficient describing metal assimilation and quantified with a total particulate concentration and a sedimentation rate. The observed sequences of relative residence times, namely $\mathrm{Zn}>\mathrm{Cu}>\mathrm{Cd}>\mathrm{Pb}$ in the loaded corrals and $\mathrm{Cu} \sim \mathrm{Zn}>\mathrm{Cd}>\mathrm{Pb}$ in the control are in good agreement with the ones calculated.

Additional metal load decreases the ability of the limnic system to lower the metal concentration. The production of phytoplankton and its assimilation capacity for metals are reduced leading to relatively higher metal concentrations in the lake (table 11). 


\section{ZUSAMMENFASSUNG}

In drei «Limno-Corrals» von $10 \mathrm{~m}$ Tiefe und $1130 \mathrm{~m}^{3}$ Inhalt wurden die Transportwege von Schwermetallen untersucht. In zwei Corrals erhöhte man die Zuflusskonzentrationen von Kupfer, Zink, Cadmium, Quecksilber und Blei auf jene Maximalwerte, die in schweizerischen Fliessgewässern vom Gesetzgeber noch tolieriert werden. Der dritte Corral diente als Kontrolle.

Die Analyse der Metallbilanzen (Fig. 8), die für eine Periode von 15 Monaten erstellt wurden, führte zum Schluss, dass zwei Hauptfaktoren die Metallelimination im Corral bestimmen, nämlich das Phytoplankton und das Periphyton.

Die Regulierung der Spurenmetallkonzentration im See wird mit einem «Steady-state»-Modell beschrieben [GI. (5)]. Darin sind die qualitativen Eigenschaften der Biomasse mit einem Verteilungskoeffizienten vertreten, der die Assimilationskapazität charakterisiert. Die quantitativen Eigenschaften werden mit Partikelkonzentration und Sedimentationsgeschwindigkeit beschrieben. Die beobachtete Reihenfolge der relativen Aufenthaltszeiten, nämlich $\mathrm{Zn}>\mathrm{Cu}>\mathrm{Cd}>\mathrm{Pb}$ in den belasteten und $\mathrm{Cu} \sim \mathrm{Zn}>\mathrm{Cd}>\mathrm{Pb}$ in den unbelasteten Corrals, entspricht der mit dem Modell berechneten Sequenz.

Die gewählte zusätzliche Metallbelastung reduziert die Fähigkeit eines limnischen Systems, die Metallkonzentration zu reduzieren. Die Produktion von Phytoplankton und seine Assimilationskapazität für Metalle werden erniedrigt. Dies führt zu einer relativ höheren Metallkonzentration im See (Tab. 11).

\section{RÉSUME}

Trois «limno-corrals» d'une profondeur de $10 \mathrm{~m}$ et d'un volume de $1130 \mathrm{~m}^{3}$ ont été employés en tant que modèles de lacs afin d'étudier les voies de transport des métaux cuivre, zinc, cadmium, mercure et plomb.

Les concentrations en métaux dans les affluents des deux corrals étaient augmentées artificiellement aux valeurs qui sont encore admises par la loi suisse. Le troisième corral servait de contrôle.

Une balance de métal a été établie pour une période de 15 mois (fig.8). Deux facteurs principaux sont responsables pour l'élimination interne des métaux, à savoir le phytoplancton et le périphyton.

La régulation de la concentration d'un métal de trace dans un lac peut être décrite à l'aide d'un modèle «steady state» [éq. (5)]. Dans ce modèle les propriétés de la biomasse sont d'une part caractérisées d'une manière qualitative par un coéfficient de partage qui décrit l'assimilation des métaux. D'autre part la concentration particulaire et la vitesse de sédimentation reflètent les relations quantitatives. Les ordres relatifs des temps de résidence observés, à savoir $\mathrm{Zn}>\mathrm{Cu}>\mathrm{Cd}>\mathrm{Pb}$ dans les corrals chargés et $\mathrm{Cu} \sim \mathrm{Zn}>\mathrm{Cd}>\mathrm{Pb}$ dans le contrôle, correspondent à ceux qui ont été calculés (tabl. 10).

Une charge de métal supplémentaire réduit la capacité d'un système limnique d'abaisser la concentration de métal. La production du phytoplancton et sa capacité d'assimilation de métaux sont réduites ce qui conduit à des concentrations en métaux relativement plus élevées dans le lac (tabl. 11).

\section{VERDANKUNG}

Wir danken Dr. D. Imboden für die wertvollen Vorschläge bei der Diskussion der Fehleranalyse, Fräulein H. Bolliger für das Zeichnen der Figuren und Frau A. Widmer für das Schreiben des Manuskriptes.

\section{REFERENCES}

1 Baccini, P.: Schweiz. Z. Hydrol. 38, 121-158 (1976),

2 Santschi, P.: Thesis, University of Bern, 1975.

3 Stumm, W., and Baccini, P.: Man-made chemical perturbations of lakes. In: Lerman, A. (ed.): Lakes-chemistry, geology, physics. Springer, New York 1978.

4 Gächter, R.: Schweiz. Z. Hydrol. 4I, 169-176 (1979).

5 Ungemach, H.: Thesis, University of Kiel, 1960. 
6 Schwarzenbach, G., and Flaschka, H.: Die komplexometrische Titration. F. Enke, Stuttgart 1965

7 Stadelmann, P.: Schweiz. Z. Hydrol. 33/1, I-65 (1971).

8 Imboden et al., D.: Schweiz. Z. Hydrol. 41, 177-189 (1979).

9 Bloesch, J.: Schweiz. Z. Hydrol. 36, 71-186 (1974).

10 Baccini, P.: unpublished results.

11 Gächter, R.: Schweiz. Z. Hydrol. 41, 277-290 (1979).

12 Gächter, R.: Schweiz. Z. Hydrol. 41, 228-246 (1979).

13 Müller, P.: Thesis, University of Zürich, 1976.

14 Stumm, W., and Morgan, J.J.: Aquatic chemistry. Wiley Interscience, New York 1970.

15 Baccini, P.: Schweiz. Z. Hydrol. 41, 291-314 (1979).

16 Zirino, A., and Yamamoto, S.: Limnol. Oceanogr. 17 (5), 661-671 (1972).

17 Bilinski et al., H.: Analyt. Chim. Acta 84, 157-164 (1976).

18 Gächter, R.: Schweiz. Z. Hydrol. 38, 97-119 (1976).

19 Riley, J.P., and Roth, I.: J. mar. biol. Ass. UK 51, 63-72 (1971).

20 Sunda, W., and Guillard, R. R.C.: J. mar. Res. 34, 511-529 (1976).

21 Gibson, C.E.: J. appl. Ecol. 9, 513-518 (1972).

22 Bundi, Th.: Thesis ETH, 1979, to be published.

23 Hatch, W.R., and Ott, W.L.: Analyt. Chem. 40, 2085 (1968).

24 Imboden, D., and Lerman, A.: Chemical models of lakes. In: Lerman, A. (ed.): Lakes-chemistry, geology, physics. Springer, New York 1978.

25 Schindler, P.W.: 1st Specialty Symposium on atmospheric contribution to the chemistry of lake waters, p. 132-145. Int. Ass. Great Lakes Res., 28 September to 1 October 1975.

Addresses of the authors: Dr. P. Baccini, E. Grieder, Seenforschungslaboratorium EAWAG/ETH, CH-6047 Kastanienbaum, Switzerland - Dr. J. Ruchti, Dr. O. Wanner, EAWAG, Überlandstrasse 133, CH-8600 Dübendorf, Switzerland. 